\title{
Comments on the paper by J. Jirásek, L. Sedláčková, M. Sivek, K. Martínek \& J. Jureczka "Castle Conglomerate Unit of the Upper Silesian Basin (Czech Republic and Poland): a record of the onset of late Mississippian C2 glaciation?"
}

\author{
JIŘí HORÁk
}

\begin{abstract}
HoRÁk, J. 2018. Comments on the paper by J. Jirásek, L. Sedláčková, M. Sivek, K. Martínek \& J. Jureczka "Castle Conglomerate Unit of the Upper Silesian Basin (Czech Republic and Poland): a record of the onset of late Mississippian C2 glaciation?" Bulletin of Geosciences 93(2), 269-274. Czech Geological Survey, Prague. ISSN 1214-1119. Manuscript received August 26, 2017; accepted in revised form March 13, 2018; published online May 29, 2018; issued June 30, 2018.
\end{abstract}

Jiři Horák, Trojanovice 592, 74401 Trojanovice; horak.sterkovny@ centrum.cz

Carboniferous strata (Namurian and lower Westphalian) of the Moravo-Silesian part of the Upper Silesian Basin have been intensively studied over 150 years. Mining coal activity resulted in a high-resolution lithostratigraphy of paralic basin infill including coal seams and marine horizons. Available data, when carefully evaluated, provide good opportunity to test existing hypothesis of global changes in the Carboniferous time. Nevertheless, it should be noted that there are a lot of unpublished reports of mining companies available in archives, which need to be taken in account. Bulletin of Geosciences published in fourth issue of 2013 a paper focused on environmental interpretation of Castle Conglomerate and its possible link with late Mississippian glaciation. In this contribution, comments on the paper by Jirásek et al. (2013) are presented.

The position of sandstones in the Poruba Members in the given article is situated in the bedrock of the Gabriela marine horizon and is named as the "Castle Conglomerate" (hereinafter referred to as CCU). This position was described as the CCU for the first time by Šusta (1928). An asset of the given article is a detailed lithology and sedimentology of the CCU position in the borehole D80/09, the Lazy Mine. The question is whether we can truly and credibly characterise the position representing the river flow and sediments covering thousands of square kilometres based only on one or two occurrences in the boreholes, together with a description of one outcrop in the fluvial bank of the Lučina river in the area of Zárubek (there are more outcrops there), and additionally reinterpreting old data. When interpreting, the authors completely ignored the total of 110 boreholes from active mines from the Karviná City area. These boreholes underwent the stratigraphic level of the $\mathrm{CCU}$, were obtained by modern drilling technology, and were properly described, including a detailed palaeontological assessment as well as borehole geophysics. Moreover, some of the boreholes obtained from the surface drilling (e.g. NP 532, NP 525, NP 543, NP 800, NP 858, SV6) are not included in the article.

The authors describe sandstone bodies of at least four stratigraphic levels as one position of the CCU. However, not every horizon (lithosome) of the conglomerate sandstones (gravelite) in the Poruba Members corresponds in fact with the CCU.

Not following recent findings when reinterpreting old survey work is not as crucial as a serious error when altering the original documentation. When there are no important horizons in the given stratigraphic interval, authors evidently make them up (e.g. the "Filip seam" in the borehole ČSM $68 / 85$ in the roof of the Gabriela marine horizon, and at the same time in the Fig. 4 it is described as the Barbora marine horizon). When we consider this particular borehole, which was difficult to interpret due to copying data mistakes, the authors came up with tectonic events; despite the fact that the original documents state that the borehole core was locally broken up. In contrast, important stratigraphic horizons are omitted, such as K-bentonite of the 424 seam (OKD) (in the D73, SuSto 515 boreholes) and especially the upper marine horizon of the upper part of the Barbora Group (borehole SuSto 515). This horizon is very crucial, because it is this particular one (the roof of the horizon) where the boundary between the Poruba and Jaklovec members is placed.

\section{Concept of development of the Ostrava Formation}

The authors present their concept of the Ostrava Formation (hereinafter referred to as OF) development in Fig. 12. The profile composed of several randomly chosen 
boreholes does not provide even the basic data about the development of the individual member units of the OF. Most of important identifying volcanogenic horizons are not stated. The boreholes from transient development between the fore-deep and platform are chosen; therefore the data concerning thicknesses are not even close to the biggest known thicknesses. In Fig. 12, some of the marine horizons of the Upper Silesian Carboniferous System are correlated with eight transgressive tracts of the sea level according to Haq \& Shutler (2008). This correlation is made in a way so that it "fits" that curve without respecting the existence of known ingressions. Moreover, a greater part of the original dating curve is utterly off the period of the OF development. There are eighty five marine ingressions recognised in the OF of the Czech part of the Upper Silesian Basin (hereinafter referred to as USB). Despite this fact, there are only twenty one marine and Lingula horizons in the picture, out of which eight (chosen according to unspecified parameters) are correlated with the rise of the world ocean level. Nevertheless, some of the rises of the sea level are correlated with clearly continental sediments.

\section{Parallelisation with Late Palaeozoic Glacial C2}

Due to disregarding findings on the development of the paralic Upper Silesian Carboniferous System (marine horizons and their faunistic content, thicknesses of units, tuffogenous horizons) the authors clearly without any basis linked the position of the $\mathrm{CCU}$ with the Late Palaeozoic Glacial C2. This was found in the Australian Carboniferous System (Fielding et al. 2008) in the period of 322.5-319.5 Ma. However, this time setting is completely off the OF onset. Such a correlation of the Australian Carboniferous System with the Upper Silesian one was possible only when some marine horizons were omitted or created (Fig. 12). Dating the Serphukhovian-Bashkirian boundary at $323.2 \mathrm{Ma}$ (Davydov et al. in Gradstein et al. 2012) and later dating of the coal tonstein 479 (OKD) in the upper part of the Poruba Members [tonstein age of the 479 seam (OKD) was defined at $325.37 \pm 0.06 \mathrm{Ma}$ (written information Schmitz, March 2014)] undeniably disproved their theory. The glacial event from the Australian Carboniferous System in the period of 322.5-319.5 Ma within the USB can be placed into the level of the Sedlové vrstvy Member or stratigraphically even higher; definitely not in the lower part of the Poruba Members. In summary, when writing this article, the authors should have known that their thoughts are completely off the OF.

\section{Thoughts on the sedimentation rate}

Calculation of the sedimentation rate (in $\mathrm{m} / \mathrm{Ma}$ ) within the Carboniferous System of the USB is disputable. Lack of knowledge of the sedimentation rate about the member's units is evident even on page 910 , where the number $330 \mathrm{~m}$ is given as the thickness between the coal tonstein of the Karel seam (No. 106 OKD) and the coal tonstein of Ludmila (most probably the 13b seam - mark according to the Staříc Mine). In fact, the thickness in the working field of the Staříc Mine (B2 - 13b) is $450 \mathrm{~m}$, and in the place of the greatest subsidence in this part of the Petřkovice Member, i.e. the Paskov Mine ( $46^{\text {th }}$ seam lower bench - I. unmarked), it is $480 \mathrm{~m}$ (e.g. Martinec et al. 2007). Apparently, the real thickness is $50 \%$ greater than it was claimed by the authors.

Another quantity for determining the course of the sedimentation is the OF onset time. The authors considered $10 \mathrm{Ma}$, which corresponds to approx. 319-329 Ma. When writing that article it must have been clear that the roof dating of the OF (319.3-321.4 Ma) does not correspond to the Serpukhovian-Bashkirian boundary (323.2 Ma, Davydov et al. in Gradstein et al. 2012). In addition to that, the greatest part - the goniatite subzone $\mathrm{E}_{2 \mathrm{c}}$ (or its part) is not present in the profile of the Upper Silesian lower Namurian. Furthermore, there is no evidence for $\mathrm{H}_{1}$ and $\mathrm{H}_{2}$ zones. This has been proved by new findings of the coal tonstein 479 (OKD) dating (written information Schmitz, March 2014). The sedimentary termination of the OF is estimated 325.2 $\mathrm{Ma}$, which corresponds to the Serphukhovian-Bashkirian boundary at 323.2 Ma (Davydov et al. in Gradstein et al. 2012). Gastaldo et al. (2009) derived the SerpukhovianViséan boundary at $329.4 \mathrm{Ma}$ (nevertheless, it does not overlay with the base of the Petrrkovice Member of the OF). The whole OF was forming roughly at 4.2 Ma.

Also, including the upper part of the Poruba Members [up to 463 seam (OKD)] into the level of Bashkirian (in Fig. 12) is considered wrong and unexplained. As even above the 499 seam (OKD) in the lower marine horizon of Gaebler, fauna of the goniatite zone $\mathrm{E}_{2}$ (boundary $\mathrm{E}_{2 \mathrm{~b}}-\mathrm{E}_{2 \mathrm{c}}$ )

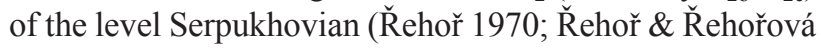
1972; Vašíček 1982, 1983) was found there. Placing the Serpukhovian-Bashkirian boundary into the seam levels of Max (461 OKD) - Natan (463 OKD) does not without doubt correspond to the absolute age of this particular boundary.

\section{Comments on correlation schemes}

As mentioned above, the authors described as one stratigraphic level of the CCU also other sandstones from at least three stratigraphic levels (sandstones' positions from the bedrock of the Jindrich seam, sandstone forming the roof of the Gabriela marine horizon and position of the sandstone from the roof of the Filip seam). The findings on development of the faunistic horizons are not taken into account, brackish and freshwater horizons are not distinguished. The authors make important changes in the identification of faunistic horizons disregarding associations 
of fauna types of individual horizons. For the first time, the Jindrrich marine horizon in their work is claimed to be a freshwater horizon; however, above the Herman seam (424 OKD), from which only freshwater fauna is known, the horizon is considered to be a marine one. The marine horizon of Jindřich (the roof of the seam No. 430 OKD) or the marine (brackish) horizon of Koksová (roof of the seam No. 420 OKD) are named as the marine horizon of Gabriela (the roof of the seam no 418 OKD). The same applies for the correlation of volcanogenic horizons. The boundary between the Poruba and Jaklovec members is placed into five various stratigraphic levels (one position is actually correct). In order to be illustrative, remarks for the published correlation schemes are attached. Very probably the authors used the same technique when analysing the listed boreholes.

\section{Comments on Figure 4}

Boreholes D80 and D73 from the Lazy Mine. - In the D80 and $\mathrm{D} 73$ boreholes within the original documentation, the Koksová Lingula horizons are described as freshwater ones. K-bentonite $424(\mathrm{OKD})$ is not marked in the profile borehole of D73. If it was, the clear correlation between the D73 and SuSto 515 boreholes would be obvious, and consequently also the identification of the 420 (OKD) and 424 (OKD) seams.

SuSto 515 borehole from the 9. květen Mine. - In this particular borehole, the authors take no account of the zoopalaeontological assessment carried out by Horák \& Hemza (1990). This assessment places the position of the CCU into the roof of the Filip seam [403 (OKD)]. In the direct bedrock of the Gabriela marine horizon (here, described as the Koksová marine horizon), there are terrigenous deposits including the coal seam; the deeper bedrock is represented by a stratigraphic equivalent of the Gustav and Filip seams. It is not possible to define the position of the CCU even in the eastern part of the former 9. květen Mine working district. In order to understand the stratigraphy of this part of the Poruba Member, it would be appropriate to mark all the faunistic horizons into the borehole profile, especially marine and tuffogenous horizons found in the borehole. The authors do not list the upper marine horizon of the upper part of the Barbora Group found in the bedrock of the seam No. 403 (OKD). This horizon is crucial for delimiting of the boundary between the Poruba and Jaklovec members. The roof of the horizon is the boundary between the Poruba and Jaklovec members. In the light of that it would be indisputable that the CCU is positioned in its upper roof, and not above the lowest Poruba seam (Filip seam, $403 \mathrm{OKD}$ ). The authors place the base of the Poruba Members into the seam itself instead of into the horizon of the Filip seam bedrock (403 OKD). Moreover, the tuffite found in the 424 seam (OKD) is not mentioned; therefore the identification of the seams Nos. 420-424 (OKD) would be evident, because this tuffogenous horizon (e.g. K-bentonite) together with marine/Lingula horizons of Koksová are present in its interlayer. They labelled the Koks seam (420 OKD) as the Herman seam (424 OKD) without noticing that the marine horizon is present in the roof of this seam (it would be the first finding of the marine fauna above the Herman seam). The Gabriela seam $(418 \mathrm{OKD})$ with the marine horizon in its roof is renamed the Koks seam (420 OKD) together with the Koksová marine horizon. The claystone from the roof of the Gustav seam $(407 \mathrm{OKD})$ is presented as the equivalent of the stable (lower) Gabriela horizon.

ČSM 68/85 borehole of the ČSM Mine. - In the article, the sandstone from the roof of the Gabriela lower marine horizon is presented as the CCU. Results of Řehořová (1985) are left out of account, and horizon of the Koks seam (420 OKD) in the freshwater development is presented as the Gabriela marine horizon. The upper position of the marine horizon of the Koks seam is in a Lingula stage by approx. $14 \mathrm{~m}$ higher. Lingula and freshwater fauna are not distinguished in the pictures; everything is labelled as "freshwater horizon". Generally speaking, Lingula horizons are important equivalents of marine horizons at seashore. In the profile above the alleged marine and freshwater horizon of Barbora [in fact it is the (lower) Gabriela marine horizon] with Lingula positions, no coal seam No. 403 (OKD) is found there in a way it is stated in the alleged profile. The presence of the seam is not confirmed even by the logging, therefore the authors made this coal position up. As it was mentioned above, it is the upper part of the Gabriela marine horizon, i.e. coast cycle sediments.

It is not possible to define the position of the $\mathrm{CCU}$ in this eastern part of the Karviná Region. The described stratigraphic level in the borehole is not seriously tectonically disturbed in a way that would suggest the presence of any tectonic disturbances, as it is stated in Fig. 4.

NP 687 Louky Borehole. - The fact that medium-grained as well as coarse-grained conglomeratic sandstones of several tens of meters in the stratigraphic profile of the Poruba Members are not unique is supported by the authors' identification of the NP 687 borehole. Instead of copying the faunistic horizon identification within this borehole for example by Řehoř (1972), they created their own identification without the assessment of the species content of individual horizons. They defined correctly the position of coarse-grained sandstones in the conglomerate; nevertheless it is a stratigraphically higher position - from the bedrock of the Jindřich marine horizon. This position is also developed even in the east of the Karviná region (see the Stonava SV2 
borehole), where the position of coarse-grained sandstones from the bedrock of the Gabriela marine horizon is difficult to distinguish. Consequently, the authors defined the $\mathrm{CCU}$ position from the bedrock of the Jindrich marine horizon and as the Barbora marine horizon they marked the lower marine horizon of Gabriela. In the Czech part of the USB, the species fauna content of the Jindřich marine horizon is so characteristic that it is impossible to mistake for some other marine horizon. The authors marked as the Jindřich marine horizon one of the freshwater horizons from the group of the Lotar faunistic horizons (the Jindrich horizon is of marine character having characteristic species fauna content in the whole Czech part of the USB including

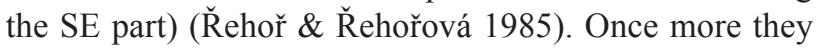
marked brackish horizons as freshwater ones - the Koksová Lingula horizon (the roof of the 420 OKD seam) is marked as the freshwater horizon of the Filip seam (403 OKD). As a result, the real Ivan seam (432 OKD) is labelled as the Koks seam (420 OKD), the real Jindřich seam (430 OKD) is labelled as the Gabriela seam (418 OKD) and the Koks seam (420 OKD) is marked as the Filip seam (403 OKD).

\section{Comments on correlation schemes - Fig. 5}

This picture represents the development of the CCU in the area of Frenštát City. The authors copied the identification of lithostratigraphy from the original reserves' calculation from the time of the geological survey (1970-1980). Errors in the identification occur in the roof of the Gabriela marine horizon in the level of the Koksová marine horizon and the Heřman seam. Therefore, at the following boreholes NP 808, NP 552, NP 826, NP 824 they created the Herman seam (424 OKD) from the Koks seam (420 OKD). Without any doubt they accepted the presence of a marine fauna in the roof of this seam, as well as high coal contents of sulphur in the seam (similar inaccuracy is evident in the SuSto 515 borehole). The coal seams 428 (OKD) are believed to be equivalents of the Herman seam.

\section{Delimitation of boundary between the Jaklovec and Poruba members}

The boundary between the Poruba and Jaklovec Members is disregarded. This boundary was defined by Řehoř \& Zeman (1958) as the roof of the highest marine position of the Barbora horizons [faunistic horizon group No. XXI (OKD)]. Within the lithological analysis of the Barbora horizons, Čepek (1989) proved the fact that just before the coal-bearing sedimentation of the Filip seam (403 OKD) there was a marine ingression as well as the development of the marine claystones [approx. 4-8 $\mathrm{m}$ below the lowest
Poruba seam - Filip (403 OKD)]. The position is several decimetres thick and from the present-day labelling we are talking about the upper horizon of the upper part of the Barbora Group. Sometimes this horizon is supported by marine fauna. To sum up the position of the boundary in Fig. 4.: borehole NP 652 - into the roof of the highest Barbora marine horizon (the only correct one); borehole D80 - into the equivalent of the Filip seam, even though the highest marine horizon was proved by fauna; borehole D73 - into the roof of the siltstones of the upper part of the lower marine horizon of the upper part of the Barbora Group (the second marine horizon from the top) below the real boundary; borehole SuSto 515 - into the Filip seam (403 OKD), in spite of the fact that the highest horizon was proved by fauna; borehole ČSM 68 - boundary is placed into the upper part of the (lower) Gabriela marine horizon; and borehole NP 687 - boundary is positioned into the roof of the (lower) Gabriela marine horizon again.

\section{Conclusions}

The asset of this article is the lithologically elaborated position of the $\mathrm{CCU}$ from two boreholes of the working field of Lazy and some at the bank outcrop of the Lučina river in Ostrava. Hence, the alluvial origin of the CCU is confirmed.

Due to the fact that authors consider any position of coarse-grained sandstones in the eastern part of the Poruba Members as the CCU, they managed to "prove" its spreading even in the east of the Karviná Region; in the mining area Stonava (the 9.květen Mine), Louky (the ČSM Mine) and Darkov (the Darkov Mine). The eastern delimitation of the body is far more to the west than the authors suggest (compare Horák et al. 2013). One of the reasons for these imprecisions is the fact that they did not include approx. 115 data boreholes, which were present at this stratigraphic level in the areas of Karviná and Frenštát.

Disregarding findings on development of the paralic Upper Silesian Carboniferous System (marine horizons and their faunistic content, thickness of units, tuffogenous horizons), the authors parallelised the position of the $\mathrm{CCU}$ with Late Palaeozoic Ice Age. This was found in the Australia Carboniferous System (Fielding et al. 2008) in the period between 322.5-319.5 Ma. Bearing this fact in mind, they must have known that this particular period interval is completely off the OF onset. The Serpukhovian-Bashkirian boundary is placed approx. $260 \mathrm{~m}$ below the real boundary, into the Max-Natan (463 OKD-461 OKD) seam of the Poruba Members.

They believe that there were only 21 marine ingressions during the sedimentation of the OF within the USB. From these, based on unknown parameters, they chose 8 ingressions and parallelised them with 8 rises of the world ocean level, 
and at the same time 4 of these rises are off the OF onset. In fact there are 85 individual marine ingressions proved in the OF.

Additionally, the ideas about the sedimentation rate are not clearly objective, as they lack knowledge about the thickness development of the individual members of the OF. Randomly chosen thickness data from boreholes, which are situated out of the area with the greatest known subsidence, are considered as the base for their assumptions. In consequence, the sedimentation rate estimations are given by placing the used borehole against the fore-deep and platform.

The authors take no account of the faunistic content of marine horizons, and parallelised interchangeably horizons of various stratigraphic levels. Similarly the parallelisation of the seams is carried out. The boundary between the Jaklovec and Poruba members established by Řehoř \& Zeman (1958) is not kept, and hence placed into different stratigraphic levels.

The major problem of this article is concealing some of the objective facts (volcanogenic horizons, Lingula horizons) found by borehole survey work, and at the same time fabricating new ones (coal positions, tectonic disturbances) if it fits their interpretation.

\section{References}

ČEPEK, P. 1989. Cyklický vývoj vybraných mořských pater ostravského souvrství československé části hornoslezské pánve a jejich význam pro korelaci uhelných slojí. [Cyclicity of selected marine horizonts in Ostrava Mb. (the Czech part of the Upper Silesian Basin and its importance for coal seam correlation)]. 10 pp. MS Generální ředitelsví Ostravskokarvinských dolů, Ostrava.

Davydov, V.I., Korn, D. \& Schmitz, M.D. with contribution Gradstein, F.M. \& Hammer, O. 2012. The Carboniferous Period, 603-651. In Gradstein, F.M., OgG, J.G., Schmitz, M.D. \& OGG, G.M. (eds) The Geological Timescale 2012. Elsevier, Amsterdam.

Fielding, C.R., Frank, T.D., Biergenheier, L.P., Rygel, M.C., Jones A.T. \& Roberts, J. 2008. Stratigraphic imprit of the Late Paleozoic Ice Age in eastern Australia: a record of the alternating glacial and nonglacial climate regime. Journal of the Geological Society 165(1), 129-164.

DOI 10.1144/0016-76492007-036

Gastaldo, R., PurkyŇová, E., ŠimưNeK, Z. \& Schmitz, M.D. 2009. Ecological persistence in the late Mississippian (Serpuchovian, Namurian A) megafloral record of the Upper Silesian Basin, Czech Republic. Palaios 24, 336-350.

DOI 10.2110/palo.2008.p08-084r

Haq, B.U. \& Shutler, S.R. 2008. A Chronology of Paleozoic Sea-Level Changes. Science 322, 64-68.

DOI 10.1126/science.1161648
Horák, J. \& Hemza, P. 1990. Zoopaleontologické vyhodnocení vrtu SuSto 515 dolu 9. květen. MS Ostravsko-karvinské doly, Důlní průzkum a bezpečnost Paskov, Paskov.

Horák, J., Martinec, P. \& Hoch, I. 2013. Porubské vrstvy, ostravské souvrství (namur A, arnsberg) v české části hornoslezské pánve. [Poruba Mb., Ostrava Fm. Namurian, Czech part of Upper Silesian Basin], 27-41. In KožUŠNíKovÁ, A. \& KoneČnÝ, P. (eds) $9^{\text {th }}$ The Czech-Polish Conference "Geology of coal basins", Documenta Geonica 2013(1). Institute of Geonics, Academy of Sciences Czech Republic, Ostrava.

JirÁsek, J., SedláčKovÁ, L., Sivek, M., Martínek, K. \& JureczKa, J. 2013. Castle Conglomerate Unit of the Upper Silesian Basin (Czech Republic and Poland): a record of the onset of Late Mississippian C2 glaciation? Bulletin the Geosciences 88(4), 893-913. DOI 10.3140/bull.geosci.1364

Martinec, P., Welser, P., Filák, P. \& Uher, A. 2007. Srovnání vulkanogenních litostratigrafických horizontů petřkovických vrstev ostravského souvrství v dobývacích prostorech „Paskov“ a "Staříčc v ostravsko-karvinském revíru. [Comparison of the lithostratigrapical horizons of volcanogenous origin in Petřkovice Mb. in mine fields Paskov and Staříč], 79-86. In LiPIARski, I. (ed.) Materialy XXX. Sympozjum Geologia formacji węglonośnych Polski. Wydawnictwo Akademia Górniczo-hutnicza im S. Staszica, Kraków.

Řenог̆, F. 1970. Die Goniatiten Zonen der Ostrava Schichtengruppe. Věstník Ústředního ústavu geologického 45, 213-216.

ŘEHOř, F. 1972. Korelace faunistických horizontů ostravského souvrství ve východní depresi československé části hornoslezské pánve. [Correlation of faunistic horizon of Ostrava Mb. in eastern part of the Czechoslovak part of the Upper Silesian Basin]. Přirodovédecký sborník vydaný k 100. výroči založení Ostravského muzea. Ostrava Muzeum, Ostrava.

ŘEHOŘ, F. \& ŘEHOŘOvÁ, M. 1972. Makrofauna uhlonosného karbonu československé části hornoslezské pánve. [Macrofauna of coalbearing Carboniferous of the Czechoslovak part of the Upper Silesian Basin]. 136 pp. 66 tab. 7 supp. Profil, Ostrava.

ŘEHOŘ, F. \& ŘEHOŘOVÁ, M. 1985. Faunistické horizonty porubských vrstev ostravského souvrství moravské části hornoslezské pánve. [Faunistic horizons of Poruba Mb. in Moravian part of Upper Silesian Basin]. Sbornik Pedagogické fakulty, Řada E-15 94, 63-81.

Řenoř, F. \& Zeman, J. 1958. Problémy stratigrafického dělení ostravských vrstev na základě nových výzkumů. [Problems of stratigraphical division of Ostrava Fm. based on new research]. Uhli 8, 234-237.

ŘEHOŘOvÁ, M. 1985. Zoopaleontologické vyhodnocení vrtu č. 68/85 dolu ČSM. [Zoopaleontological evaluation of borehole No. 68/85]. MS Ostravsko-karvinské doly, Důlní průzkum a bezpečnost Paskov, Paskov.

Šusta, V. 1928. Stratigrafie ostravsko-karvinské oblasti ve světle paleontologie. 341-429. [Stratigraphy of Ostrava-Karviná 
Coal District in the light of paleontology]. In KAMENoUHELNÉ DOLY OSTRAVSKO-KARVINSKÉHO REVÍRU (ed.) Ředitelská konference ostravsko-karvinského kamenouhelného revíru, Ostrava.

VAŠíčEK, Z. 1982. Konodonti Gaeblerova mořského horizontu karvinské části OKR (namur A). [Conodonts of Gaebler marine horizon in Karviná area OKR (Namurian A)]. Přirodovědecký sbornik Ostravského muzea 26, 167-179.

VAŠíČEK, Z. 1983. Beitrag zu den juvenilen Goniatiten des marinen Gaeblers-Horizonts. [Tschechoslowakischer Teil des oberschlesischen Beckens, Namur A]. Časopis Moravského muzea 68, 29-56. 